involvement by an interval of 2-8 years. The remaining seven cases presented with bronchial disease 3 weeks to 10 months before any evidence of primary disease could be discovered. The present case is unique in that the metastatic endobronchial disease appeared $9 \frac{1}{2}$ years after resection of the primary lesion. Because of its segmental location, the tumour could have been missed by rigid bronchoscopic examination. The diagnosis was made quickly with the flexible fibreoptic bronchoscope, and the patient was spared the inconvenience of further studies.

\section{References}

Braman, S.S. \& WhitcomB, M.E. (1975) Endobronchial metastasis. Archives of Internal Medicine, 135, 543.

CAPlaN, H. (1959) Solitary endobronchial metastasis from carcinoma of kidney. British Journal of Surgery, 46, 624.

Case Records of the Massachusetts General Hospital (1947) Case \#33012, New England Journal of Medicine, 236, 38.

Case Records of the Massachusetts General Hospital (1972) Case \#13-1972, New England Journal of Medicine, 286, 713 .

Gerle, R. \& Felson, B. (1963) Metastatic endobronchial hypernephroma. Diseases of the Chest, 44, 225.
Higginson, J.F. (1955) A study of excised pulmonary metastatic malignancies. American Journal of Surgery, 90, 241.

King, D.S. \& Castleman, B. (1943) Bronchial involvement in metastatic pulmonary malignancy. Journal of Thoracic Surgery, 12, 305.

Maytum, C.K. \& Vinson, P.P. (1936) Pulmonary metastasis from hypernephroma with ulceration into a bronchus simulating primary bronchial carcinoma. Archives of Otolaryngology, 23, 101.

NoRfsingeR, C.D. \& VINSON, P.P. (1942) Intrabronchial metastasis of hypernephroma simulating primary bronchial carcinoma. Journal of the American Medical Association, 119, 944.

Rosenblatt, M.B., LiSA, J.R. \& Trinidad, S. (1966) Pitfalls in the clinical and histologic diagnosis of bronchogenic carcinoma. Diseases of the Chest, 49, 396.

Seiler, H.H., Clagett, D.T. \& MCDonald, J.R. (1950) Pulmonary resection for metastatic malignant lesions. Journal of Thoracic Surgery, 19, 655.

Silverberg, S.G., Evans, R.H. \& Koehler, A.L. (1969) Clinical and pathologic features of initial metastatic presentations of renal cell carcinoma. Cancer, 23, 1126.

Tinney, W.S. \& McDonald, J.R. (1945) Pulmonary metastasis of carcinoma diagnosed by bronchosocopy. Minnesota Medicine, $28,554$.

Vinson, P.P. \& Martin, W.J. (1932) Pulmonary metastasis from hypernephroma diagnosed by bronchoscopy. Archives of Otolaryngology, 15, 368.

WILlis, R.A. (1952) The Spread of Tumours in the Human Body, p. 172. Butterworth, London.

\title{
Nephrotic syndrome, sickle-cell disease and pregnancy
}

\author{
Alan M. SMith \\ M.A., B.M., B.Ch., M.R.C.P., F.R.C.S.(Fd.), F.R.C.O.G. \\ New Cross Hospital, Wolverhampton
}

\begin{abstract}
Summary
A young West Indian with sickle-cell disease and the nephrotic syndrome in the last trimester of pregnancy was treated after admission to hospital with folic acid and blood transfusion. Labour was induced by intravenous prostaglandin $E_{2}$ but the fetus died. The nephrotic syndrome resolved but the proteinuria, the cause of which it is suggested is a true sickle-cell nephropathy, persisted.
\end{abstract}

\section{Introduction}

Individuals with a sickle-cell disease may now survive well into adult life because infection is no longer a common cause of early death and crises are more effectively treated (Huntsman and Lehmann, 1974). As the life-span becomes longer, renal complications are more frequently recognized. One of these is the nephrotic syndrome, which may be the result of a specific glomerulonephritis (Miller et al., 1964; Walker et al., 1971). Pregnancy complicated by sickle-cell anaemia is uncommon (Buckle, 1968; Beacham and Beacham, 1950; Hendrickse et al., 1972), and the added complication of the nephrotic syndrome is rare.

\section{Case report}

An unmarried 21-year-old West Indian, known to have homozygous sickle-cell disease, was admitted as an emergency with suspected pre-eclampsia in the thirty-second week of her second pregnancy. When 17 years old, she had aborted spontaneously after 7 weeks of amenorrhoea. There was no record of the blood pressure nor of urinalysis before pregnancy.

The patient, $158 \mathrm{~cm}$ tall, was of slight build and 
weighed $50 \mathrm{~kg}$. The raised blood pressure $(150 / 110$ $\mathrm{mmHg}$ ) was associated with moderate generalized oedema and gross proteinuria. The size of the uterus was compatible with the amenorrhoea and the fetal heart sounds were normal.

The haemoglobin initially was $6.9 \mathrm{~g} / \mathrm{dl}$ with a reticulocyte count of $20 \%$ and varied between $6.1 \mathrm{~g}$ and $7 \cdot 1 \mathrm{~g} / \mathrm{dl}$ until just before delivery. The blood film showed sickle cells and electrophoresis confirmed the presence of haemoglobin $\mathbf{S}$ alone. The serum iron $(49.2 \mu \mathrm{mol} / \mathrm{l})$ excluded iron deficiency. The urine contained more than 30 pus cells per high power field but no red cells or casts, and was sterile. At first the proteinuria, composed mainly of albumin was $8.0 \mathrm{~g} / 24 \mathrm{hr}$. The plasma proteins were $52 \mathrm{~g} / \mathrm{l}$ (albumin $24.5 \mathrm{~g} / \mathrm{l}$, globulin $27.5 \mathrm{~g} / \mathrm{l}$ ) with increased $\alpha_{1}$ - and $\beta$-globulin. The IgG at $5.5 \mathrm{~g} / \mathrm{l}$ was lower than normal (range $6.0-14.0 \mathrm{~g} / \mathrm{l}$ ); the IgM $1.26 \mathrm{~g} / 1$ was normal (range $0.55-2.2 \mathrm{~g} / \mathrm{l}$ ); the $\mathrm{IgA}$, $5.15 \mathrm{~g} / \mathrm{l}$, was increased slightly (normal range 0.90 $4.5 \mathrm{~g} / \mathrm{l})$. The blood urea was $8.0 \mathrm{mmol} / \mathrm{l}$. The $24-\mathrm{hr}$ urinary oestriol excretion was $27 \cdot 8 \mu \mathrm{mol} / 24 \mathrm{hr}$.

The patient was lethargic but not breathless. First class protein was added to her diet as well as folic acid $5.0 \mathrm{mg}$ daily.

She was sedated with amylobarbitone sodium and the blood pressure remained at $150 / 100 \mathrm{mmHg}$ but the oedema steadily increased. Attacks of limb and trunk pain responded to analgesics and were diminished in frequency and severity by moving the patient to a warm room. By the end of the thirtyfifth week the fetus was judged to be dysmature. The 24-hr urinary excretion of oestriol had fallen to $13.9 \mu \mathrm{mol} / 24 \mathrm{hr}$. The blood urea had risen to 9.7 $\mathrm{mmol} / 1$ while the proteinuria had increased to 18.5 $\mathrm{g} / 24 \mathrm{hr}$, and the plasma proteins had declined to $40.0 \mathrm{~g} / 1$ (albumin $16.0 \mathrm{~g}$; globulin $24.0 \mathrm{~g}$ ) with inincreased $\alpha_{2}$ - and low $\gamma$-globulin. No fibrinogen degradation products were found in the peripheral blood and the prothrombin time, the partial thromboplastin time, and the fibrinogen titre were all normal. After transfusion of a $1 \cdot 1$ litre volume of blood the haemoglobin rose to $10.4 \mathrm{~g} / \mathrm{dl}$. The following day, the patient had frontal headache, epigastric pain and a blood pressure of $160 / 100 \mathrm{mmHg}$. Labour was therefore induced by an intravenous infusion of prostaglandin $\mathrm{E}_{2}$ without amniotomy; the initial dose was $0.25 \mu \mathrm{g} / \mathrm{min}$ which was increased every $30 \mathrm{~min}$. The fetal heart rate was monitored by an external ultrasound technique and uterine contractions recorded by external tocography. Regrettably, fetal death occurred quite suddenly after $8 \mathrm{hr}$ of labour. Delivery was normal after a labour of $13 \mathrm{hr}$, following which the blood pressure was 140/90 $\mathrm{mmHg}$. Ampicillin was injected intra-muscularly during labour, followed by oral ampicillin and later tetracycline which was given for 10 days because a high vaginal swab taken during labour grew Klebsiella sp., sensitive only to tetracycline. Pyrexia $\left(38^{\circ} \mathrm{C}\right)$ which occurred during labour, settled immediately after delivery and was attributed to the prostaglandin $\mathrm{E}_{2}$ infusion.

Post-mortem of the fetus $(2 \cdot 19 \mathrm{~kg})$ showed no abnormality apart from changes due to anoxia. The cord blood contained haemoglobin F. The placenta $(350 \mathrm{~g})$ was normal macroscopically and there was no microscopic abnormality.

On day 3 of the puerperium the haemoglobin was $8.7 \mathrm{~g} / \mathrm{dl}$. By day 4 the blood urea was $5.3 \mathrm{mmol} / \mathrm{l}$ but the urine still contained protein $10.4 \mathrm{~g} / 24 \mathrm{hr}$ and the plasma proteins were $39 \mathrm{~g} / 1$ (albumin $15 \mathrm{~g}$, globulin $25 \mathrm{~g}$ ). The creatinine clearance was 108 $\mathrm{ml} / \mathrm{min}$. The urine grew Escherichia coli in spite of antibiotic therapy, but this bacilluria later resolved.

On day 7 , the serum IgG had risen to $10.8 \mathrm{~g} / \mathrm{l}$, the urine IgG was $0.33 \mathrm{~g} / \mathrm{l}$, serum transferrin $1.5 \mathrm{~g} / \mathrm{l}$ and the urine transferrin $0.26 \mathrm{~g} / \mathrm{l}$; the selectivity index was $0 \cdot 17$.

By the fourth week the oedema had subsided completely, and the blood pressure settled to $130 / 90$ $\mathrm{mmHg}$. The haemoglobin had continued to decline to $7.9 \mathrm{~g} / \mathrm{dl}$, while the plasma proteins had risen to $65 \mathrm{~g} / \mathrm{l}$ (albumin $33 \mathrm{~g}$, globulin $32 \mathrm{~g}$ ).

At the sixth week the blood pressure was 125/70 $\mathrm{mmHg}$, the proteinuria approximately $3 \mathrm{~g} / 24 \mathrm{hr}$, and the plasma albumin was normal. The selectivity index, estimated in the Regional Laboratory, was 0.1315 months after delivery. The patient remained symptom-free with persistent proteinuria and the haemoglobin remained approximately $7 \mathrm{~g} / \mathrm{dl}$. She declined contraceptive advice.

\section{Discussion \\ Diagnosis}

The cause of the nephrotic syndrome in this patient remains in doubt. Renal biopsy was not performed because it would have been dangerous in a pregnant woman with sickle-cell anaemia and the nephrotic syndrome. However, renal biopsy seems safe in pregnant women with pre-eclampsia as well as in patients with homozygous sickle-cell disease who are not pregnant (Petrucco et al., 1974). After delivery when the nephrotic syndrome had resolved, biopsy was not required. The selectivity index of 0.17 indicated a moderately selective glomerular permeability such as is found in pre-eclampsia or membranous glomerulonephritis. The index later fell to $\mathbf{0 \cdot 1 3}$, indicating a highly selective glomerular permeability and, if these findings were correct, suggests that the renal lesion had altered (Simanowitz and Macgregor, 1974). Perhaps changes due to preeclampsia remitted while chronic renal disease, probably a long standing sickle-cell nephropathy, 
continued. The absence of blood fibrinogen degradation products, however, implies that there was no true pre-eclampsia (Wood et al., 1974). The nephrotic syndrome may be the result of a glomerulonephritis caused by the blocking of small renal vessels by clumps of sickle cells not only in the glomerulus but also in the vasa recta of the renal medulla (Van Eps et al., 1970). Pyuria and bacilluria, common in sickle-cell anaemia, are likely to have been secondary to some other form of chronic renal disease in this patient. No doubt sickle-cell disease may cause or be associated with the nepthrotic syndrome in various ways (Berman and Tublin, 1959; McCoy, 1969).

\section{Mangagement of nephrotic syndrome}

Diuretics were not used for fear that reduction of the blood volume might precipitate a sickle-cell crisis by increasing the blood viscosity. Very high protein diets are recommended and undoubtedly the patient did not eat enough first class protein.

An infusion of salt-free albumin would have increased the blood volume temporarily, corrected the hypoalbuminaemia, and caused a diuresis (Davison et al., 1974). Correction of the hypoalbuminaemia might have improved the fetal prognosis provided that the blood volume remained increased and the placental insufficiency improved. However, the proteinuria was so great that most of the infused albumin would have been swiftly lost and the benefit of short duration.

Corticosteroids were not given because they are generally ineffective if there is a moderately selective proteinuria. They are not recommended in the nephrotic syndrome due to sickle-cell disease (Berman and Tublin, 1959).

Repeated exchange blood transfusion, as recommended by Bellina and Bickers (1974), would conceivably have improved placental and renal efficiency, possibly by controlling the number of sickle cells but, in practice, Hendrickse et al. (1972) have found no improvement and mention the risks of serum hepatitis. Clumping of sickle cells may trap normal transfused cells, which are then rapidly lost, and result in micro-infarction, particularly in the kidney.

\section{Obstetric management}

Maternal morbidity and mortality are increased when pregnancy is complicated by homozygous sickle-cell disease. Pain in the abdomen and in bone was not severe enough to warrant heparin therapy in this patient and responded to simple measures. Folic acid prevented a secondary megaloblastic anaemia. Blood was transfused to improve the anaemia during labour in case an emergency Caesarean section was required. Otherwise blood transfusion is withheld unless the haemoglobin is less than $6 \mathrm{~g} / \mathrm{dl}$, or if there is infection, pseudotoxaemia or sequestration (Hendrickse et al., 1972).

Induction was performed in this case because of suspected fetal dysmaturity, rising blood urea, rising blood pressure and increasing proteinuria. Serial estimation of the fetal biparietal diameter would have confirmed or otherwise the severity of intrauterine growth retardation. Prostaglandin $E_{2}$ was infused intravenously because amniotomy could be avoided and the chance of intra-uterine infection reduced. For the same reason an intra-uterine catheter and the Cardiff infusion system were not used although an extra-amniotic catheter might have obviated this problem (Calder, Embrey and Hiller, 1974). Broad-spectrum antibiotics were given to prevent infection, to which nephrotics are peculiarly prone: infection might have precipitated a sicklecell crisis. The pyrexia in labour was attributed to the prostaglandin infusion. Intra-uterine fetal death was due to placental insufficiency resulting from sickle-cell anaemia, hypertension, hypoproteinaemia, and presumed low blood volume. Dehydration and metabolic acidosis, which may equally precipitate a sickle-cell crisis, were prevented by an intravenous infusion of $5 \%$ dextrose. Caesarean section might have saved the fetus but the maternal risk would have been considerable, for wound infection with delayed healing and venous thrombosis might occur even if the risks of anaesthesia could be easily overcome. Caesarean section is generally reserved for contracted pelvis in the presence of sickle-cell disease (Hendrickse et al., 1972).

The problem of contraception is not easily solved because oestrogen-containing oral contraceptives may precipitate thrombosis and infection could follow the insertion of an intra-uterine device. Sterilization might be considered when the patient has had a small family or at least one surviving child.

\section{Acknowledgment}

I am grateful to the Regional Immunological Laboratory, East Birmingham Hospital, for the immunoglobulin assays.

\section{References}

Beacham, W.D. \& Beacham, D.W. (1950) Sickle-cell disease and pregnancy. American Journal of Obstetrics and Gynecology, 60, 1217.

BellinA, J.H. \& BiCKers, J.N. (1974) Modern management of sickle-cell disease in pregnancy. Southern Medical Journal, 67, 426.

Berman, L.B. \& Tublin, I. (1959) The nephropathies of sickle-cell disease. Archives of Internal Medicine, 103, 602.

BuCKLE, A.E.R. (1968) Sickle-cell disease in pregnant immigrants. Postgraduate Medical Journal, 44, 836.

CAlder, A.A., Embrey, M.P. \& Hiller, K. (1974) Extraamniotic prostaglandin $E_{2}$ for the induction of labour at term. Journal of Obstetrics and Gynaecology of the British Commonwealth, 81, 39. 
Davison, A.M., Lambie, A.T., Verth, A.H. \& Cash, J.D. (1974) Salt-poor human albumin in management of nephrotic syndrome. British Medical Journal, 1, 481.

HeNDRICKSE, J.P. DE V., HARRison, K.A., Watson-Williams, E.J., Luzzatto, L. \& AJabor, L.N. (1972) Pregnancy in homozygous sickle-cell anaemia. Journal of Obstetrics and Gynaecology of the British Commonwealth, 79, 396.

Huntsman, R.G. \& LehmanN, H. (1974) Treatment of sickle-cell disease. British Journal of Haematology, 28, 437.

McCoY, R.C. (1969) Ultastructural alterations in the kidney of patients with sickle-cell disease and the nephrotic syndrome. Laboratory Investigation, 2, 85.

Miller, R.E., Hartley, M.W., Clark, E.C. \& Lupton, C.H. (1964) Sickle-cell nephropathy. Alabama Journal of Medical Science, 1, 233.

Petrucco, O.M., Thomson, N.M., Lawrence, J.R. \& WELDON, M.W. (1974) Immunofluorescent studies in renal biopsies in pre-eclampsia. British Medical Journal, 1, 473.

Simanowitz, M.D. \& Macgregor, W.G. (1974) A critical evaluation of renal protein selectivity in pregnancy. Journal of Obstetrics and Gynaecology of the British Commonwealth, 81, 196.

Van Eps, Statius L.W., Pinedo-Veels, C., de Vries, G.H. \& DE KONING, J. (1970) Nature of concentrating defect in sickle-cell nephropathy. Lancet, i, 450.

Walker, B.R., Alexander, F., Birdsall, T.R. \& Warren, R.L. (1971) Glomerular lesions in sickle-cell nephropathy. Journal of the American Medical Association, 215, 437.

Wood, S.M., Burnett, D., Picken, A.M., Farrell, A.M. \& Wolf, P. (1974) Assessment of coagulation and fibrinolysis in pre-eclampsia. British Medical Journal, 2, 145. 